\title{
Романычев И.С. \\ Доверие пожилых людей к социальным службам как феномен общественного сознания
}

Институт дополнительного профессионального образования работников сочиальной сферь

(Россия, Москва)

doi: $10.18411 / l j-02-2021-238$

idsp: ljournal-02-2021-238

Аннотация

В статье рассматриваются концептуальные вопросы доверия пожилых граждан к социальным службам. Констатируются причины превалирования недоверия со стороны определённых групп пожилых людей, анализируется институциональность и персонифицированность доверия. Подчёркивается важность соблюдения этических прерогатив для эволюции персонифицированного доверия в доверие институциональное.

Ключевые слова: социальная служба, социальная защита, социальное обслуживание, социальная помощь, социальный работник, пожилой человек, государство, доверие.

\section{Abstract}

The article deals with the conceptual issues of senior citizens ' trust in social services. The author states the reasons for the prevalence of distrust on the part of certain groups of older people, analyzes the institutionality and personification of trust. The importance of observing ethical prerogatives for the evolution of personalized trust into institutional trust is emphasized.

Keywords: social service, social protection, social service, social assistance, social worker, elderly person, state, trust.

Вопросы доверия граждан к социальным, экономическим и политическим институтам остаются актуальными вне зависимости от политического режима, формы правления, экономического уклада. На первый взгляд может показаться, что в условиях демократии вопрос доверия несоизмеримо более важен, чем при авторитарных или тоталитарных режимах. Однако даже при слабой развитости обратной связи между властью и народом остаётся актуальным вопрос наличия социальной базы, на которую власть может положиться. Эта социальная база представляет собой не только чиновничий слой или бюрократию, но и массу иных групп граждан, которые готовы в определённый момент выразить вотум доверия существующему строю и политической элите, если не встать на защиту устоявшегося порядка. Поддерживать эти группы, а вернее, работать над их уровнем доверия к строю, порядку и элите, является важной задачей сферы государственного управления. Данные группы могут различаться по возрасту, социально-экономическому положению, месту проживания и многим другим параметрам. В данной статье автор пытается рассмотреть концептуальные вопросы формирования и поддержания доверия такой огромной социально-демографической группы, как пожилые люди, к сфере, которая наиболее отражает стремление государства поддерживать наиболее обездоленные и уязвимые слои населения социальной защите. Эта сфера представлена ежедневной деятельностью социальных служб - организаций, предоставляющих социально-экономическую помощь, социально-бытовые и социально-медицинские услуги на дому, возможность постоянного (стационарного) проживания и многое другое. 
Ещё Конфуций говорил, что в случае крайней нужды власть может отказаться от вооружения или продовольствия, но не от доверия народа, ибо «если народ перестанет верить, то государству не устоять». В Толковом словаре С. И. Ожегова доверие определяется как «чувство или убеждение, что такому-то лицу, обстоятельству или надежде можно доверять, верить; вера в надёжность кого-либо, чего-либо». Польский социолог П. Штомпка пишет о доверии, как об «ожидании добросовестного поведения других лиц по отношению к нам». Э. Гидденс определяет доверие как «веру в надёжность человека или системы». В общем и целом можно остановиться на следующих положениях: 1) доверие подразумевает позитивную оценку; 2) доверие способствует готовности к взаимодействию; 3) доверие является мотивационным фактором в деятельности. Доверие имеет социально-психологическую природу, далеко не всегда выражается в экономических или социально-статистических показателях, но всегда стратегически влияет на все процессы взаимодействия государства и общества. Доверие обладает мощным релаксирующим эффектом, оно «успокаивает» коллективного субъекта, предостерегает его от отчаяния и деструктивных действий.

Доверие может подразделяться на институциональное и персонифицированное. Во втором случае речь идёт о доверии к личности (президенту, главе правительства, губернатору, руководителю, служащему). Однако для рассмотрения вопроса о доверии к целой системе служб уместно остановиться на институциональных аспектах, тем более что система социальной защиты населения традиционно выступает как устоявшийся и признанный «агент» социального государства по регулированию латентных конфликтов, снижению социальной напряжённости, укреплению солидарности между поколениями. Более полумиллиона работников социальных служб (центров социального обслуживания, интернатов (пансионатов) для престарелых и инвалидов, центров помощи семье и детям, реабилитационных центров и др.) регулярно взаимодействуют с гражданами, находящимися в состоянии нуждаемости, или, по-старому, в трудной жизненной ситуации. Весь спектр социальной проблематики - бедность, немощность, одиночество, бездомность, насилие в семье, социальная дезадаптированность - является предметом профессиональной деятельности по повышению качества жизни социально-уязвимых граждан, росту их ресурсного потенциала, улучшению их взаимодействия с внешней средой.

Пожилые люди составляют примерно четверть населения России. По данным Росстата, на начало 2019 года численность лиц старше трудоспособного возраста (или достигших официально установленного пенсионного возраста) составила 37 млн 362 тыс. человек или 25,4\% населения Российской Федерации (в 2005 году - 29 млн 353 тыс. человек и 20,4\% соответственно). Последние несколько десятилетий в общественном сознании за пожилыми людьми прочно закрепился имидж социальноуязвимой группы населения. Здесь присутствует и экономическая уязвимость - как правило, низкий уровень доходов; и биологическая уязвимость - ограниченность в самообслуживании, передвижении, высокая потребность в медико-социальных услугах; и социально-психологическая уязвимость - чувство одиночества, снижение качества психического функционирования. И это только основные аспекты поступательно снижающегося с возрастом качества жизни. Пожилые люди удерживают первое место по охвату деятельностью социальных служб - свыше 60 \% всех социальных услуг на территории России предоставляется пожилым гражданам (далее идут инвалиды, семьи с детьми, бездомные). В этих условиях крайне актуализируется вопрос доверия пожилых людей к социальным службам, в том числе тех пожилых, которые не являются потребителями социальных услуг (пенсионное обеспечение не в счёт, поскольку Пенсионный Фонд формально не входит систему социальной защиты населения и представляет собой особую вертикаль организаций и ведомств). Именно неохваченные социальными услугами пожилые люди часто оперируют слухами и домыслами о работе организаций социального обслуживания, формируют у себя не 
всегда объективно обусловленные установки в отношении, например, социальных работников. Они являются носителями того самого коллективного мнения, которое, может быть, не всегда верное с объективных позиций, но всегда отражает как закономерности, так и тренды общественного мышления, а с ними необходимо считаться и социологам, и власть предержащим.

Важнейшим моментом, отражающим противоречивость феномена доверия к социальным службам, является уполномоченность социальных служб государством. Как известно, государственные институты первыми попадают под удар народного недоверия, когда речь идёт о нарастающей напряжённости и кризисных явлениях в экономике и социальной сфере. Выражается это в патологической обвиняемости государства и государственных органов, ведь именно на них многие граждане склонны возлагать ответственность за всё происходящее. Причём государственные органы можно обвинять как в действиях, так и в бездействии. И здесь интересно то, что с одной стороны, социальные службы ассоциируются, естественно, с государством, с другой стороны - именно они должны помогать людям справляться с невзгодами. При наличии этой помощи (адресной социальной помощи в виде продуктовых наборов, товаров длительного пользования, социальных картах, единовременных выплатах и т. д.) ожидается, что это поспособствует снижению социальной напряжённости. Государство, которое провоцирует проблемы и само же помогает их решать - феномен, существующий в сознании именно получателей социальной помощи. И для государства это лучше, чем если бы оно ассоциировалось исключительно с разрастанием социальных проблем. Не случайно то, что в кризисные периоды государство стремится увеличить количество получателей помощи, пусть даже ценой снижения среднего объёма помощи. Пожилые люди в такие периоды, как правило, оказываются в положении уязвимых наряду с трудоспособным населением, склонны чаще посещать отделы социальной защиты населения, центры социального обслуживания и иные социальные службы с целью нахождения экономической поддержки в виде субсидий, выплат, компенсаций, гуманитарной помощи т. п.

Работники социальных служб не случайно заявляют о том, что посещающие их пожилые люди склонны обвинять государство в своих невзгодах и распространять эти обвинения на работников. Такие фразы, как «вы здесь сидите, зарплату получаете, а мы голодаем», «вы тоже власть, вот вы и ответьте нам, чего так плохо живём», «мы всю жизнь работали, а вы сейчас на нас наживаетесь» являются ничем иным, как следствием мысленного проецирования феномена государства (или власти) на лиц, которые действительно уполномочены государством, но на деле не представляют собой важного звена в распределении властных полномочий. В определённой степени, это отношение к работникам социальных служб как к чиновникам - главным обвиняемым в отдалённости от нужд и интересов народа. В таких случаях работникам социальных служб очень важно выдерживать корректный тон разговора, соблюдать этику, выслушивать человека, сочувствовать ему, поскольку благодаря этому напряжённость может хотя бы немного снизиться. В периоды социальных неурядиц многим людям не хватает элементарного понимания, и именно работники социальных служб должны профессионально подходить к блокированию напряжённости на уровне индивида, осуществлять работу с позиций гуманизма, который в народе получил название «человеческое отношение».

К этому стоит добавить, что малейший отход работников от гуманитарных принципов, нарушение этики, попрание моральных норм, пусть даже проявившиеся только в процессе общения с посетителями, вызовут цепочку слухов о хамском отношении социальных служб к пожилым людям и инвалидам, неумении работать с населением. Таким образом, проблема, касающаяся только одного работника, в общественном сознании гипертрофируется до проблемы всей социальной сферы. Этому трудно будет противодействовать, так как общественное сознание склонно 
обобщать любую проблематику. Пострадает от этого, в первую очередь, уровень доверия к социальным службам, в особенности со стороны тех граждан, которые не являлись получателями социальной помощи, не имеют собственного опыта взаимодействия с социальными службами, а потому более доверчиво относятся к отрицательным суждениям. Результат этого проявится в социологических данных по вопросу доверия к государственным и общественным институтам, где рейтинг организаций социальной сферы будет снижен.

Другое направление работы социальных служб - предоставление социальнобытовых, социально-медицинских и иных услуг на дому - является самым массовым направлением социального обслуживания пожилых граждан и инвалидов. По данным Росстата, на 2018 год социальное обслуживание на дому получали 1176678 граждан пожилого возраста и инвалидов. Социальные услуги предоставляли 135983 социальных работника. Наиболее востребованными услугами остаются покупка и доставка продуктов питания и товаров первой необходимости, содействие в проведении уборки, помощь в оплате жилищно-коммунальных услуг, сопровождение на прогулку или в учреждения здравоохранения, содействие в обеспечении лекарственными средствами (формулировки названий услуг могут различаться в зависимости от региона, где утверждался перечень услуг). Социальный работник остаётся важным звеном во взаимосвязи пожилого человека с внешней средой, выполняет ведущую роль в поддержании качества жизни одиноких или одиноко проживающих граждан, ограниченных в самообслуживании.

Вопрос доверия к социальным службам именно в рамках социального обслуживания на дому раскрывается в более глубоком ключе, нежели в случае с экономической помощью. Дело в том, что экономическая помощь более проста в восприятии общественным сознанием, и поверхностные взгляды на суть и смысл материальной поддержки самоподтверждаются простыми механизмами её предоставления. В случае же с социальным обслуживанием на дому речь идёт, вопервых, о более приватной сфере взаимоотношений между социальным работником и получателем социальных услуг, во-вторых, о длительном создании адаптивной среды вокруг пожилого человека, в-третьих, о решении целого комплекса проблем, не всегда связанного с финансовым положением пожилого человека. Как следствие, общественное сознание чаще склонно ошибаться в отношении надомного обслуживания, нежели в отношении предоставления материальной помощи. Вместе с тем, за последние два десятилетия произошло расширение восприятия деятельности социального работника - от ассоциаций с простой доставкой продуктов до признания в нём профессионала, взаимодействующего с различными организациями, представляющего интересы пожилого человека, владеющего разнообразными навыками поддержания социально-бытовой обустроенности получателя социальных услуг.

Недоверие к социальному обслуживанию на дому, а конкретнее, к деятельности социального работника, может исходить из следующих установок. Во-первых, боязнь, что социальные службы завладеют жилищем пожилого человека. Во-вторых, при покупке продуктов и иных товаров некоторое количество денег может быть присвоено социальным работником. Сюда же можно отнести боязнь воровства личных вещей пожилого человека. В-третьих, надомное социальное обслуживание - это распространение персональных данных, которыми могут воспользоваться мошенники, связанные с социальными службами. В-четвёртых, при оказании медико-социальных услуг любая манипуляция может навредить пожилому человеку, поэтому лучше пусть это делают профессиональные медики в медицинских учреждениях. Это далеко не все установки, но даже среди них присутствуют различные варианты трактовок, вплоть до того, что социальные службы якобы регулируют смертность пожилых людей, чтобы жилищный фонд освобождался по некоему намеченному плану. В общем и целом, 
подобные установки чаще присутствуют в сознании тех пожилых граждан, кто никогда не сталкивался с социальным обслуживанием. Отчасти это может быть обусловлено слухами (часто не имеющими отношения именно к социальным работникам), отчасти уровнем тревожности многих пожилых граждан, которые ощущают собственную социальную уязвимость и беззащитность перед мошенничеством, непрофессионализмом или равнодушием. Многие примеры того, что социальный работник встаёт на защиту интересов пожилого, поступаясь своим свободным временем и иными ресурсами, редко воспринимаются как правда, или же воспринимаются как нечто естественное, поскольку в понимании многих граждан социальные работники должны жертвовать собой. Негативная информация усваивается лучше, обрастает домыслами, а потому сильнее влияет на установки многих граждан.

В отличие от негативных, доверительные установки, также имеющиеся в сознании многих граждан преклонного возраста, зачастую связаны с феноменом заботы и помощи. Причём этот феномен отражает потребность в услугах далеко не разового характера, а скорее в создании вокруг пожилого человека максимально благоприятной среды, где его ограниченность в самообслуживании компенсируется прямыми действиями социального работника. Для многих пожилых людей социальный работник - едва ли не последний в жизни человек, с которым можно поговорить о наболевшем, которому можно довериться, с которым ассоциируется завтрашний день. И нельзя отрицать тот факт, что доверие к социальным службам может присутствовать также в установках пожилых, никогда не получавших социальные услуги, но осознающих смысл работы этих организаций и выстраивающих стратегию взаимодействия со сферой социального обслуживания в недалёком будущем. То же может касаться и стационарного социального обслуживания в интернатах (пансионатах) для пожилых и инвалидов, о которых могут ходить абсолютно разные слухи, но без которых некоторые пожилые люди не видят своего будущего.

Если вернуться к дихотомии «институциональное доверие персонифицированное доверие» и попытаться констатировать взаимосвязь между двумя явлениями, то в первую очередь стоит рассмотреть контактный уровень взаимодействия между пожилым человеком и социальными службами. Именно там формируется доверие (или недоверие) персонифицированное, причём оно может касаться сразу нескольких работников социальной службы - например, специалиста по социальной работе, ведущего приём населения, или социального работника, предоставляющего прямые услуги, или заведующего отделением. При взаимодействии с этими работниками клиент обращает внимание на несколько важных для него аспектов: насколько внимательно он был выслушан, нашёл ли он видимое понимание своей проблемы, насколько оперативно работники среагировали на проблему, насколько принятое решение удовлетворяет потребности клиента. От соблюдения этических нормативов начинает зависеть очень многое, в особенности когда выясняется, что социальная служба не в состоянии в полной мере помочь человеку. Поэтому для работников социальных служб крайне важно соблюдать позитивноэмпатийное содержание коммуникации с клиентом. В конце концов, существует целая категория клиентов, которые обращаются в социальные службы только для того, чтобы выговориться. Возрастные аспекты в данном случае играют очень большую роль, поскольку одиночество и невостребованность многих пожилых людей заставляют их искать коммуникативное поле, и социальным службам здесь отводится едва ли не первое место.

Сформированное персонифицированное доверие может трансформироваться в доверие институциональное, однако первоначально это касается только тех граждан, которые обращались в социальные службы или получали социальные услуги. Для иных категорий продолжает оставаться важной информационная составляющая, исходящая от соседей, знакомых, родственников, а равно черпаемая из средств массовой информации. От того, насколько в обществе представлена установка, что «в соцзащите 
работают хорошие люди», зависит, как ни странно, формирование и развитие институционального доверия на самом широком уровне. Этическая компонента может всерьёз превалировать над компонентой рациональной, отражающей результативность работы социальных служб. Это происходит ещё и потому, что эффективность и результативность работы социальных служб не всегда видны напрямую - они завуалированы в системе социальных отношений, сохранении общественной стабильности, Общественное сознание не всегда может констатировать, где именно проявляется результат работы сферы социальной защиты населения, в то время как информация о характере актов взаимодействия с работниками данной сферы быстро становится достоянием социума.

Эволюция персонифицированного доверия к работникам социальных служб в доверие институциональное ещё нуждается в изучении. Однако можно констатировать, что социальные службы - мощный и значимый представитель государства во взаимодействии с гражданами, тем более с такой широкой социальной группой, как пожилые люди. Доверие к решениям и действиям работников социальных служб знаменует одну из ступеней в формировании доверия к государственным органам в целом, к существующему политическому режиму, к социально-экономическому укладу. Деятельность сферы социальной защиты населения позволяет нивелировать множество социальных проблем, в первую очередь касающихся пожилых граждан, и направить вектор социально-политического развития на достижение общественного согласия и социальной сплочённости. При этом никогда нельзя недооценивать этический компонент во взаимодействии граждан и социальных служб, поскольку именно он задаёт направление в формировании доверительных отношений, перерождающихся от контактного к макросоциальному уровню.

$$
* * *
$$

1. Демидова Т.Е. и др. Социальная работа с пожилыми людьми: Монография / Г.П. Медведева, Т.Е. Демидова. - Москва: РУСАЙНС, 2017. - 264 с.

2. Нагорнова А.Ю. Теория и технология социальной работы с пожилыми людьми: учебное пособие для академического бакалавриата / А. Ю. Нагорнова. - 2-е изд., испр. и доп. - М. : Издательство Юрайт, 2018. - 152 с. — (Серия: Университеты России).

3. Ожегов С.И. и Шведова Н.Ю. Толковый словарь русского языка: 80000 слов и фразеологических выражений / Российская академия наук. Институт русского языка им. В.В. Виноградова. 4-е изд., доп. М.: Азбуковник, 1998.

4. Переломов Л.С. Конфуций: жизнь, учение, судьба. М.: Наука; Издательская фирма «Восточная литература», 1993.

5. Росстат: официальный сайт. https://rosstat.gov.ru/

6. Теория социальной работы: учебник для магистров / Е.И. Холостова [и др.]; под общ. ред. Е.И. Холостовой, Е.Г. Студеновой. - М.: ИТК «Дашков и К», 2018. - 474 с.

7. Фирсов М.В., Студенова Е.Г. Теория социальной работы (для бакалавров). Учебник / Фирсов М.В., Студенова Е.Г. - Москва: КноРус, 2018. - 322 с.

8. Хасанова Г.Б. Социальная геронтология: учебное пособие / Г.Б. Хасанова.- М.: ИНФРА-М, 2018.$171 \mathrm{c}$.

9. Штомпка П. Доверие - основа общества / Пер. с польск. Н.В. Морозовой. М.: Логос, 2012.

\section{Семенова А.Н., Чочиева А.Н., Коркмазова Ф.И. Понятие и причины экстремизма среди молодежи}

Северо-Кавказская государственная академия (Россия, Черкесск)

doi: $10.18411 / l j-02-2021-239$

idsp: ljournal-02-2021-239

\section{Аннотация}

Масштабностью определяется проблемы распространения экстремизма среди молодежи и необходимостью изучения причин данного явления для успешного противодействия. 